\title{
Angewandte
}

Supporting Information

(c) Wiley-VCH 2005

69451 Weinheim, Germany 


\section{Orthogonally Protected Sugar Diamino Acids as Novel Building Blocks for Linear and Branched Oligosaccharide Mimetics}

Frank Sicherl and Valentin Wittmann*

\section{Experimental Section}

17: $\beta$-Alanine amide 13 (27 mg, $0.067 \mathrm{mmol})$ was dissolved in dry DMF (4 mL) and treated with piperidine $(1 \mathrm{~mL})$. After $40 \mathrm{~min}$, the solvent was removed under reduced pressure followed by co-evaporation with toluene. The residue was re-dissolved in $\mathrm{CHCl}_{3}(3 \mathrm{~mL})$ and 2 (44 mg, $0.081 \mathrm{mmol})$ and a solution of HBTU (31 mg, $0.081 \mathrm{mmol})$ and HOBt $(19 \mathrm{mg}$, $0.121 \mathrm{mmol})$ in dry DMF $(3 \mathrm{~mL})$ were added. $i \operatorname{Pr}_{2} \mathrm{NEt}(31 \mu \mathrm{L}, 0.202 \mathrm{mmol})$ was added and the mixture was stirred over night. After dilution with $\mathrm{CHCl}_{3}(15 \mathrm{~mL})$, the organic phase was washed with $0.1 \mathrm{~N} \mathrm{HCl}$ and sat aq $\mathrm{NaHCO}_{3}$, dried with $\mathrm{Na}_{2} \mathrm{SO}_{4}$ and evaporated. Purification by flash chromatography (silica, EtOAc/MeOH 95/5) gave $17(42 \mathrm{mg}, 89 \%): R_{\mathrm{F}}=0.5$ (EtOAc/MeOH 9/1).

18: Peptide 17 (50 mg, $0.071 \mathrm{mmol})$ was dissolved in dry DMF (4 mL) and treated with piperidine $(1 \mathrm{~mL})$ for $30 \mathrm{~min}$. After evaporation and co-evaporation with toluene, the remaining solid was dissolved in $\mathrm{CHCl}_{3}(8 \mathrm{~mL})$ and building block 1 ( $\left.88 \mathrm{mg}, 0.142 \mathrm{mmol}\right)$, a solution of HATU (54 mg, $0.142 \mathrm{mmol}$ ) and HOAt (29 mg, $0.214 \mathrm{mmol})$ in DMF (8 mL), and $i \operatorname{Pr}_{2}$ NEt $(55 \mu \mathrm{L}, 0.356 \mathrm{mmol})$ were added. After stirring over night, aqueous workup as described for 17 followed. Flash chromatography (silica, EtOAc/MeOH 95/5) gave 18 (61 mg, $79 \%): R_{\mathrm{F}}=0.53($ EtOAc/ $\mathrm{MeOH} 9 / 1)$.

19: To a solution of $18(50 \mathrm{mg}, 0.046 \mathrm{mmol})$ in THF (4 mL) $\mathrm{PMe}_{3}(278 \mu \mathrm{L}, 1 \mathrm{M}$ in THF) and water $(1 \mathrm{~mL})$ were added. After $1 \mathrm{~h}$, the mixture was evaporated and co-evaporated several times with toluene. The subsequent peptide coupling was carried out as described for $\mathbf{1 7}$ using 2 eq of 1. Purification by flash chromatography (silica, EtOAc/MeOH 95/5) gave 19 (56 mg, $73 \%): R_{\mathrm{F}}=0.48\left(\right.$ EtOAc/MeOH 9/1); RP-HPLC (Vydac 218TP54 $\mathrm{C}_{18}$ reversed-phase column, $4 \times 250 \mathrm{~mm}$, flow $=1 \mathrm{~mL} \mathrm{~min}^{-1}, 20-80 \%$ acetonitrile in water $/ 0.1 \%$ TFA over $30 \mathrm{~min}$ ): $t_{\mathrm{R}}=24.0 \mathrm{~min}$. HRMS (MALDI-FTICR), calcd for $\mathrm{C}_{83} \mathrm{H}_{110} \mathrm{~N}_{8} \mathrm{O}_{27}: 1673.73730[M+$ $\mathrm{Na}^{+}$], found: $1673.73587, \Delta m=0.8 \mathrm{ppm}$. 
20: Protected oligomer $19(15 \mathrm{mg}, 0.009 \mathrm{mmol})$ was dissolved in $\mathrm{CHCl}_{3} / \mathrm{THF} 1: 1(1 \mathrm{~mL})$ and stirred for $1 \mathrm{~h}$. The mixture was evaporated and the remainder was dissolved in $\mathrm{MeOH}$ $(500 \mu \mathrm{L})$, treated with $1 \mathrm{~N} \mathrm{HCl}(500 \mu \mathrm{L})$ for $1 \mathrm{~h}$, and lyophilized. Finally, stirring with $20 \%$ piperidine in DMF $(500 \mu \mathrm{L})$ led to complete deprotection. Purification by RP-HPLC (Vydac 218 TP54 $\mathrm{C}_{18}$ reversed-phase column, $4 \times 250 \mathrm{~mm}$, flow $=1 \mathrm{~mL} \mathrm{~min}^{-1}, 1-100 \%$ acetonitrile in water $/ 0.13 \%$ pentafluoropropionic acid over $30 \mathrm{~min}, t_{\mathrm{R}}=15.5 \mathrm{~min}$ ) gave $20 \cdot 4 \mathrm{~F}_{3} \mathrm{C}-\mathrm{CF}_{2}-\mathrm{CO}_{2} \mathrm{H} \quad\left(3.5 \mathrm{mg}, 28 \%\right.$ ). HRMS (ESI-FTICR, $\mathrm{MeCN} / \mathrm{H}_{2} \mathrm{O}$ ), calcd for $\mathrm{C}_{31} \mathrm{H}_{50} \mathrm{~N}_{8} \mathrm{O}_{13}: 743,35696\left[M+\mathrm{H}^{+}\right]$, found: 743.35563, $\Delta m=1.8$ ppm (see Figure $\mathrm{S}-1$ ).

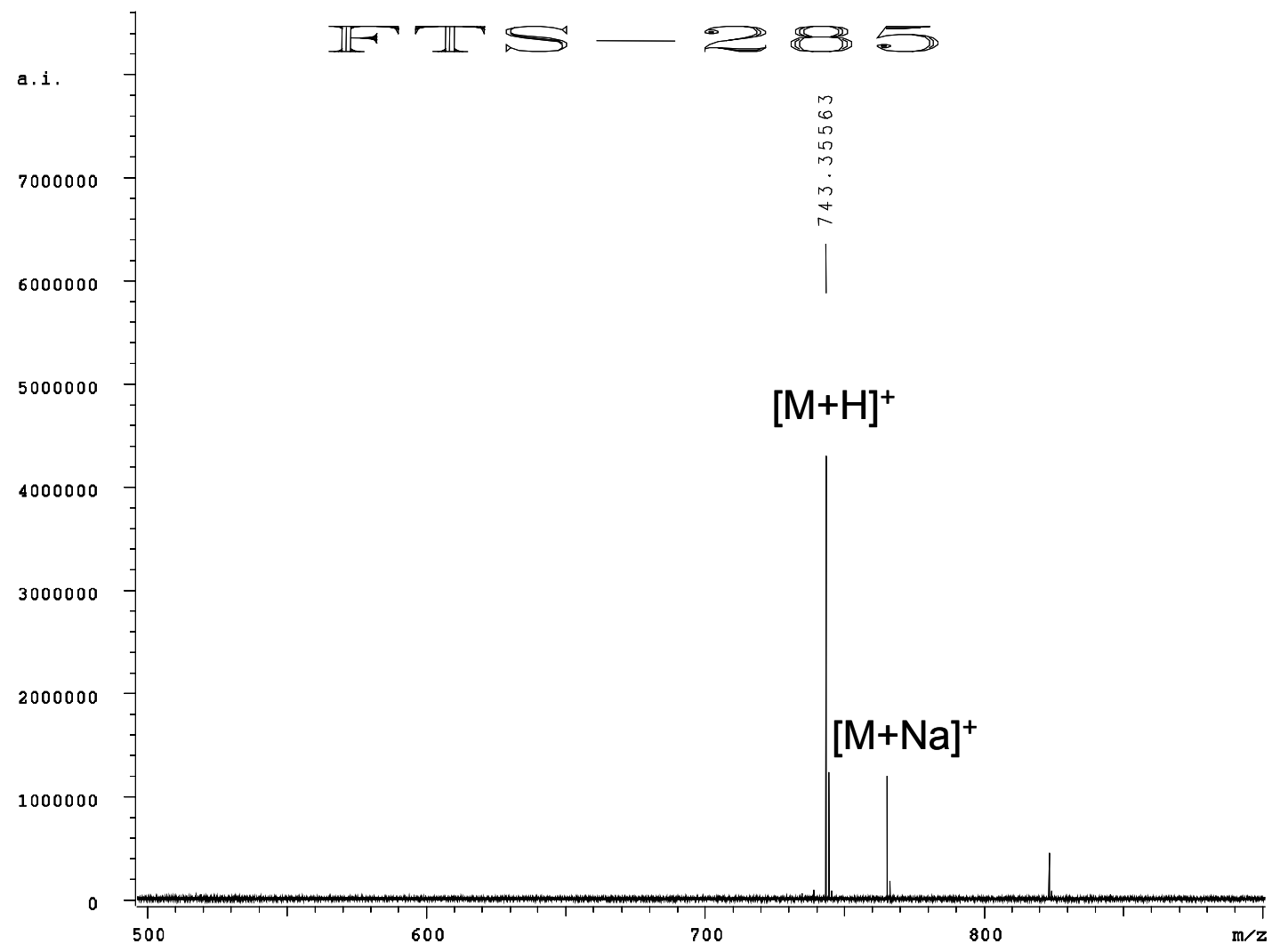

Figure S-1. HRMS (ESI-FTICR, $\mathrm{MeCN} / \mathrm{H}_{2} \mathrm{O}$ ) of 20. 